\title{
Back to the Future: Reflections on the History of the Future of Family Medicine
}

\author{
Noemi C. Doohan, MD, PhD, Jill Endres, MD, MS, Nerissa Koehn, MD, \\ John Miller, MD, MPH, Joseph E. Scherger, MD, MPH, James Martin, MD, and \\ Jennifer E. Devoe, MD, DPhil
}

These are historic times for family medicine. The profession is moving beyond the visionary blueprint of the Future of Family Medicine (FFM) report while working to harness the momentum created by the FFM movement. Preparing for, and leading through, the next transformative wave of change (FFM version 2.0) will require the engagement of multigenerational and multidisciplinary visionaries who bring wisdom from diverse experiences. Active group reflection on the past will potentiate the collective work being done to best chart the future. Historical competency is critically important for family medicine's future. This article describes the historical context of the development and launch of the FFM report, emphasizing the professional activism that preceded and followed it. This article is intended to spark intergenerational dialog by providing a multigenerational reflection on the history of FFM and the evolution that has occurred in family medicine over the past decade. Such intergenerational conversations enable our elders to share wisdom with our youth, while allowing our discipline to visualize history through the eyes of future generations. (J Am Board Fam Med 2014;27:839-845.)

Keywords: Health Policy, Medical Education, Primary Health Care

There is an urgent need for a strong and sustainable US health care system. Family medicine is uniquely positioned to lead efforts to help our nation achieve the triple aim of better health care, improved population health, and lower health care costs. ${ }^{1-5}$ Reflections on the history of family medicine are central to our dialog about the future, including a critical review of key historical docu-

This article was externally peer reviewed.

Submitted 9 March 2014; revised 5 June 2014; accepted 30 June 2014.

From the University of California, Riverside, School of Medicine, Riverside, CA (NCD); Department of Family Medicine, University of Iowa Roy J. And Lucille A. Carver College of Medicine, Iowa City, IA (JE); Family Medicine Residency of Western Montana (NNK, JBM), College of Health Professions and Biomedical Sciences, University of Montana, Missoula, MT; Eisenhower Medical Center, Rancho Mirage CA (JES); CHRISTUS Santa Rosa Health System, San Antonio,TX (JCM); and Department of Family Medicine, Oregon Health and Science University, Portland, OR (JED).

Funding: none.

Conflict of interest: JED is an editorial board member of the $7 A B F M$.

Corresponding author: Noemi C. Doohan, MD, PhD, UC Riverside School of Medicine, School of Medicine Research Building, 900 University Ave, Riverside, CA 92521 (E-mail: drmidrmi@earthlink.net). ments, such as the Future of Family Medicine (FFM 1.0) report. ${ }^{6-9}$ Reviewing the history surrounding the creation of the FFM 1.0 report will help our profession prepare for the next wave of transformative recommendations (FFM 2.0). ${ }^{10}$ This article presents a multigenerational perspective on the historical context of the development and the launch of the FFM 1.0 report, emphasizing the professional activism that preceded and followed it. It is intended to spark continued intergenerational dialog on the evolution that has occurred in family medicine over the past decade as well as to provide historical context for critically interpreting and building an action plan for FFM 2.0 recommendations. Effective change will require the engagement of multigenerational and multidisciplinary visionaries who bring wisdom from diverse experiences. Historical competency is imperative; active group reflection on the past will potentiate the collective work being done to best chart the future.

\section{Historical Context, Development, and Launch of the FFM 1.0 Report}

Family medicine derived from general practice. Before the 20th century, the standard medical practice 
was that of general practitioners making house calls for urgent illnesses. After World War II, outpatient offices were built near rapidly expanding hospitals funded by the Hill Burton Act. The future of general practice became uncertain as medical disciplines increasingly specialized in certain diseases and organ systems. ${ }^{11,12}$ Recognizing the need for physicians to care for the whole person and coordinate patient care, the 1966 Willard $^{13}$ and Millis ${ }^{14}$ reports called for a new residency-trained specialty to replace general practice. To further support the need for comprehensive approaches to caring for individual and community health, the 1967 Folsom Report called for "communities of solution." Founded as "family practice" in 1969 , the specialty flourished in the 1970s. ${ }^{16}$ In addition to providing care for acute illnesses, family physicians were tasked with managing chronic health problems and navigating the emerging preventive health recommendations. The founders recognized that behavior drives health, and thus behavioral education and biopsychosocial models have been an integral part of family medicine training from the beginning. ${ }^{17,18}$

By the late 20th century, family physicians were spending the majority of their time delivering episodic care in outpatient settings. Despite changes in the organization and financing of health care delivery, Green et $\mathrm{al}^{19}$ demonstrated in 2001 that the US "ecology of medical care" had not changed significantly from when it was first assessed by White et $\mathrm{al}^{20}$ in 1961. Primary care was essential for the health of the nation; a majority of patients received medical care in primary care physician's offices, and a majority of those office visits were provided by family physicians. ${ }^{19}$

In 1998, the Institute of Medicine Committee on the Quality of Care in America published an influential report: "Crossing the Quality Chasm: A New Health System for the 21st Century." ${ }^{21}$ This report warned that the US health care system was fatally flawed and required a massive overhaul to shift from episodic office-based care to a continuous process of care between a team and a population of patients using advanced information systems. This new system should provide collaborative, patientcentered, evidence-based, high-value, equitable, and safe care. ${ }^{21}$

With the realization that radical changes were needed to propel the discipline of family medicine into the 21 st century, family physician leaders gath- ered (for the third time) in Keystone, Colorado, in $2000 .^{22}$ In what became known as Keystone III, multigenerational representatives from the 7 family medicine organizations engaged in a "structured conversation about family practice in the United States" to "examine the soul of the discipline of family medicine" and "to take stock of the present and grapple with the future of family practice."23

Building on recommendations and discourse from Keystone III, the FFM Project was officially launched in 2002. ${ }^{24}$ This historic project came at a time of increasing health care costs and diminishing care quality; health care disparities were worsening, delivery of evidence-based care was sporadic, and an increasing percentage of the population was uninsured. ${ }^{25-28}$ Fragmentation of care was predominant; few systems were organized, integrated, or coordinated to place patients at the true center of care. ${ }^{28,29}$ Widely considered to be a failure, the trial of managed care led to physicians' demoralization and patients' distrust in the system. ${ }^{30}$ Family medicine was poorly understood by patients and family physicians were undervalued by payers and experienced a lack of prestige. ${ }^{31}$ This dire external view of family medicine was exacerbated by changes in the profession's scope of practice and lack of consensus on professional priorities. At the same time, interest in primary care among medical students was plummeting. ${ }^{32}$

FFM 1.0 leaders organized 5 task forces (later adding a sixth) with representatives from all $7 \mathrm{na}$ tional family medicine organizations and other experts external to the field. Qualitative research involving interviews with "thought leaders" and focus groups of physicians and patients was performed by independent research firms. ${ }^{24}$ They identified 5 key characteristics of family physicians and issued the following identity statement: "Family physicians are committed to fostering health and integrating health care for the whole person by humanizing medicine and providing science-based, high-quality care." 24

The FFM 1.0 report called for major changes to family medicine and to the US health care system. Its principles were widely shared with the public and were featured by major media outlets. For family medicine to achieve excellence in delivering science-based, high-quality care for the whole person and to lead the transformation of primary care, the report recommended bringing about changes in 4 key areas: (1) the US health care system, (2) 
clinical practice, (3) training and continuing development, and (4) leadership and communication.

\section{The US Health Care System}

The FFM 1.0 Report had 10 recommendations addressing the role of family medicine in improving US health care. A key recommendation described a "new model" of care entitled the patient-centered medical home (PCMH). ${ }^{24}$ This concept, first described in the pediatric community in the 1960 s, ${ }^{33-35}$ was seen as a transformational design for family medicine to address issues related to access to care and the quality and efficiency of patient care and to embed new and relevant technological advances into practice. ${ }^{36}$ In 2005, Ostbye et $\mathrm{al}^{37}$ estimated that a primary care physician without a team would need at least 18 hours per day to provide high-quality care to a panel of patients. Given this impossibility, the PCMH was envisioned to improve efficiency by relying on a team of caregivers all working to the highest level of their licenses. ${ }^{38}$ The PCMH characteristics were further articulated in a document released in 2007 by the Robert Graham Center. ${ }^{36,39-41}$ The PCMH concept received significant positive attention by the media and the public and was embraced by many primary care stakeholders, payers, and politicians. ${ }^{42}$ However, the cost of building the required clinical office infrastructure has not been supported by current payment models, ${ }^{43-46}$ so the adoption of PCMHs within the primary care community has been slow, and the value and viability of the PCMH remains a concern. ${ }^{47,48}$

The timeliness of the FFM 1.0 Report facilitated an opportunity to influence the Affordable Care Act (ACA) - the largest health reform legislation in more than 50 years; key concepts from the report were embedded in ACA legislation. ${ }^{49}$ Fueled by the FFM 1.0 Report, the ACA developed policies to shift the US health care system toward a primary care-centered model intended to improve quality at decreased cost, with better systems for managing population health. ${ }^{50}$ The FFM Report also laid important groundwork for the integration, implementation, and "meaningful use" of electronic health records into the health care system. ${ }^{51-53}$

\section{Clinical Practice}

A goal of the FFM 1.0 process was to identify the core attributes of family physicians. FFM 1.0 outlined the vision for a scope of practice that encom- passed a comprehensive approach to caring for the whole person and suggested operationalizing this vision through a "basket of services." Over the past decade, studies have highlighted key areas within family medicine's traditional scope with decreasing involvement by family physicians. ${ }^{54}$ For example, the percentage of prenatal visits that were provided by family physicians decreased by 50\% from 1995 to 2004, a decline that continued through $2010 .^{55,56}$ Family physicians' provision of care to children has similarly declined: One study reported a $33 \%$ decrease in the percentage of children's office visits provided by family physicians and general practitioners between 1992 and 2002. ${ }^{57}$ Another study reported a decrease in the percentage of family physicians providing children's health care: from $78 \%$ to $68 \%$ between 2000 and $2009 .{ }^{58}$ Some experts point to the fact that the number of pediatricians doubled from 1981 to 2004, while the birth rate decreased. ${ }^{57}$ Further, the number of family physicians providing care in hospitals has steadily decreased; an increasing percentage of hospital care is now provided by hospitalists, only $10.5 \%$ of whom are family physicians. ${ }^{59,60} \mathrm{~A}$ similar trend toward outpatient-only practice has occurred among general internists. ${ }^{57}$

A full basket of services and a broad scope of practice were envisioned by FFM 1.0, yet many family physicians have not maintained this traditional scope because of several factors, including malpractice insurance, reimbursement, lifestyle priorities, credentialing, and lack of support from other medical specialists. ${ }^{61-63}$ At the same time, an increasing percentage of family physicians are engaged in comprehensive prevention and chronic illness management for individuals, as well as in caring for communities and populations, demonstrating that family medicine has expanded in complexity, if not in scope. ${ }^{64,65}$

\section{Training and Continuing Development}

Research informing FFM 1.0 revealed that family medicine training requirements were viewed as rigid and not well suited to meet the future needs of the health care system. The FFM 1.0 Report responded by calling for the Residency Review Committee (RRC) to enhance educational "flexibility and responsiveness, innovation and active experimentation, consistency and reliability, individualized to learner's needs and the needs of communities." 24 In turn, the RRC approved a key innovation 
project in 2007: the Preparing the Personal Physician for Practice (P4) Initiative. ${ }^{66}$ Administered by TransforMED, a clinical practice national support resource founded by the American Academy of Family Physicians (and also an FFM 1.0 recommendation), the project selected 14 residency programs to implement innovative changes, including duration of training and curriculum content. ${ }^{67,68}$ In 2013, the discipline launched a second pilot addressing duration of training and scope of practice. In 2014, the RRC revised the Accreditation Council for Graduate Medical Education core program requirements, stressing PCMH competencies, population health, and quality improvement training. ${ }^{69}$ While longitudinal studies of these innovative projects will require years to complete, preliminary findings show improvements in care of chronic illnesses, ${ }^{66}$ successful examples of practice transformation and improvement, ${ }^{67,70,71}$ and a new model for providing tailored residency education experiences. ${ }^{68}$ One promising sign is that more US medical school seniors chose family medicine through the National Resident Matching Program in 2013 than in any year since $2002 .^{72,73}$

Beyond medical school education and residency training, FFM 1.0 recognized lifelong learning and career development for family physicians as critically important for the health of the profession. This recognition coincided with the creation of a process called Maintenance of Certification by the American Board of Medical Specialties, which was implemented by the American Board of Family Medicine $^{74}$. In 2010, 91\% of all active, board-certified family physicians eligible for Maintenance of Certification were participating in this training, with demonstrated improvement in the quality of medical care delivered. ${ }^{75,76}$ This high level of engagement in career-long learning is seen as one of the top achievements of FFM 1.0 and has served as a model for other specialty boards.

\section{Leadership and Communication}

FFM 1.0 emphasized the need to strengthen the identity of family medicine by defining and promoting a public message via a combination of strategies aimed at communicating consistency and purpose. As part of this messaging, the name of the specialty, and of the certifying board, was officially changed from "family practice" to "family medicine.”
Research was identified as being critical to the profession; thus FFM 1.0 called for development of a collaborative research agenda for studying the origins of illness, improving care provision, and expanding traditional practice-based research. While a cohesive national family medicine research agenda remains only a recommendation, the Robert Graham Center in Washington, DC, has played a crucial role in informing ongoing FFM efforts and continues to evaluate progress toward its goals.

The FFM 1.0 Report recognized that the broad training and diverse vantage points of family physicians enable them to play a vital leadership role in the transformation of the US health care system. There was a call for an expansion in leadership training opportunities and for academic departments to develop programs to address this need. FFM 1.0 also called for the development of a leadership center for family medicine and primary care, which has yet to be fully realized.

\section{Conclusions}

Family medicine's history of positive change and growth over the past decade is a testament to the vision and foresight of the founders of the specialty more than 40 years ago and, more recently, to that of the FFM 1.0 creators and contributors. FFM 1.0 was a critical first step toward ensuring that family physicians are equipped and positioned to drive the changes needed for the US health care system to achieve the triple aim, but more work is needed to realize all FFM 1.0 goals and to set FFM 2.0 goals. ${ }^{10}$ Family medicine must continue to transform at an accelerated pace to best meet the needs of patients and influence vital improvements in the US health care system. As the profession moves forward, continued study of the history of family medicine will help ensure that all family medicine learners and teachers know where we've been to better see where we are going, thereby building historical competency within the profession. For example, a group of young leaders revisited the historic Folsom Report and highlighted its relevance regarding communities of solutions for today's complex health problems. ${ }^{9,15}$ Intergenerational dialog about how best to interpret and learn from this history will meaningfully inform the future. The future of family medicine as a profession and as an academic discipline will depend on effectively passing the baton from the current FFM leadership to the next generation. 


\section{References}

1. Stream G. Having your say on the future of family medicine. Leawood (KS): American Academy of Family Physicians; 2013. Available from: http://www.aafp. org/news-now/opinion/20130910ffm2.html/. Accessed September 10, 2013.

2. Baird MA. Primary care in the age of reform-not a time for complacency. Fam Med 2014;46:7-10.

3. Scherger JE. The unfinished story of family medicine transformation. Fam Med 2014;46:5-6.

4. Berwick DM, Nolan TW, Whittington J. The triple aim: care, health, and cost. Health Aff (Millwood) 2008;27:759-69.

5. Calman NS, Golub M, Shuman S. Primary care and health reform. Mt Sinai J Med 2012;79:527-34.

6. Bliss E, Cadwallader K, Steyer TE, et al. A view from Cheyenne Mountain: Generation III's perspective of Keystone III. Ann Fam Med 2014;12:75-8.

7. Stange KC, Frey III JJ. Unresolved intergenerational issues. Ann Fam Med 2014;12:5-6.

8. Rowland $\mathrm{K}$. The voice of the new generation of family physicians. Ann Fam Med 2014;12:6-7.

9. Folsom Group. Communities of solution: the Folsom Report revisited. Ann Fam Med 2012;10: 250-60.

10. Doohan NC, Duane M, Harrison B, Lesko S, DeVoe JE. The Future of Family Medicine version 2.0: reflections from Pisacano Scholars. J Am Board Fam Med 2014;27:142-50.

11. Gutierrez C, Scheid P. The history of family medicine and its impact in US health care delivery. Leawood (KS): AAFP Foundation; 2002. Available from: http:// www.aafpfoundation.org/online/etc/medialib/found/ documents/programs/chfm/foundationgutierrezpaper. Par.0001.File.tmp/foundation-gutierrezpaper.pdf. Accessed September 20, 2014.

12. Starr P. The social transformation of American medicine. New York: Basic Books; 1982.

13. American Medical Association. Ad Hoc Committee on Education for Family Practice. Council on Medical Education. Meeting the Challenge of Family Practice. Chicago: American Medical Assocation; 1966. (Also known as the "Willard Report").

14. Citizens Commission on Graduate Medical Education. The Graduate Education of Physicians. Chicago: American Medical Association; 1966. (Also known as the "Millis Report").

15. Health is a community affair-report of the National Commission on Community Health Services (NCCHS). Cambridge (MA): National Commission on Community Health Services; 1967.

16. Tobbell D. Plow, town, and gown: the politics of family practice in 1960s America. Bull Hist Med 2013;87:648-80.

17. Collaborative Family Healthcare Association [homepage on the Internet]. Available from: www.cfha.net. Accessed December 26, 2013.
18. Engel GL. The need for a new medical model: a challenge for biomedicine. Science. 1977;196:129-36.

19. Green LA, Fryer GE Jr, Yawn BP, Lanier D, Dovey SM. The ecology of medical care revisited. New Engl J Med 2001;344:2021-5.

20. White KL, Williams TF, Greenberg BG. The ecology of medical care. New Engl J Med 1961; 265:885-92.

21. Institute of Medicine. Crossing the quality chasm: a new health system for the 21st century. Washington, DC: National Academies Press; 2001.

22. Green LA, Graham R, Frey JJ, Stephens GG. Keystone III: The role of family medicine in a changing health care environment: a dialogue. Washington, DC: Robert Graham Center; 2001.

23. Green LA, Graham R, Stephens GG, Frey JJ. A preface concerning Keystone III. Fam Med 2001;33: 230-1.

24. Martin JC, Avant RF, Bowman MA, et al. The Future of Family Medicine: a collaborative project of the family medicine community. Ann Fam Med 2004;2(Suppl 1):S3-32.

25. Levit K, Smith C, Cowan C, Lazenby H, Sensenig A, Catlin A. Trends in U.S. health care spending, 2001. Health Aff (Millwood) 2003;22:154-64.

26. Institute of Medicine. Care without coverage: too little, too late. Washington, DC: National Academies Press; 2002.

27. Institute of Medicine. Unequal treatment: what health care providers need to know about racial and ethnic disparities in health care. Washington, DC: National Academies Press; 2002.

28. Institute of Medicine. To err is human: building a safer health system. Washington, DC: National Academies Press; 2000.

29. Stange KC. The problem of fragmentation and the need for integrative solutions. Ann Fam Med 2009; 7:100-3.

30. Robinson JC. The end of managed care. JAMA 2001;285:2622-8.

31. Leigh JP, Tancredi D, Jerant A, Romano PS, Kravitz RL. Lifetime earnings for physicians across specialties. Med Care 2012;50:1093-101.

32. Biola H, Green LA, Phillips RL, Guirguis-Blake J, Fryer GE. The U.S. primary care physician workforce: undervalued service. Am Fam Physician 2003; 68:1486.

33. American Academy of Pediatrics Ad Hoc Task Force on Definition of the Medical Home: The medical home. Pediatrics 1992;90:774.

34. Sia C, Tonniges TF, Osterhus E, Taba S. History of the medical home concept. Pediatrics. 2004;113(5 Suppl):1473-8.

35. Sia CJ, Antonelli R, Gupta VB, et al. The medical home. Pediatrics. 2004;110:184-6.

36. The patient centered medical home: history, seven core features, evidence and transformational change. 
Washington, DC: The Robert Graham Center; 2007.

37. Ostbye T, Yarnall KS, Krause KM, Pollak KI, Gradison M, Michener JL. Is there time for management of patients with chronic diseases in primary care? Ann Fam Med 2005;3:209-14.

38. Ghorob A, Bodenheimer T. Share the care: building teams in primary care practices. J Am Board Fam Med 2012;25:143-5.

39. Stenger RJ, Devoe JE. Policy challenges in building the medical home: do we have a shared blueprint? J Am Board Fam Med 2010;23:384-92.

40. Kellerman R, Kirk L. Principles of the patient-centered medical home. Am Fam Physician. 2007;76: 774-5.

41. Patient-centered medical home: building evidence and momentum: a compilation of PCMH pilot and demonstration projects. Washington, DC: PatientCentered Primary Care Collaborative; 2008.

42. Clay MA 2nd, Sikon AL, Lypson ML, et al. Teaching while learning while practicing: reframing faculty development for the patient-centered medical home. Acad Med 2013;88:1215-9.

43. Berenson RA, Rich EC. US approaches to physician payment: the deconstruction of primary care. J Gen Intern Med 2010;25:613-8.

44. Schultz S, Abercrombie S, Crownover B, et al. Accountable care organizations: an opportunity for synergy. Ann Fam Med 2013;11:283-4.

45. Kirschner N, Doherty RB; American College of Physicians Medical Service Committee. A system in need of change: restructuring payment policies to support patient-centered care: a Position Paper of the American College of Physicians. Philadelphia: American College of Physicians; 2006.

46. Patient-centered medical home special report. $\mathrm{PCMH}$ likely to form basis of federal health care reform. Leawood (KS): American Academy of Family Physicians; 2009. Available from: http://www.aafp.org/news/ $\mathrm{pcmh} / 20090217 \mathrm{pcmhfedreform} . h \mathrm{tml}$. Accessed September 20, 2014.

47. Peikes D, Zutshi A, Genevro JL, Parchman ML, Meyers DS. Early evaluations of the medical home: building on a promising start. Am J Manag Care 2012;18:105-16.

48. Arend J, Tsang-Quinn J, Levine C, Thomas D. The patient-centered medical home: history, components, and review of the evidence. Mt Sinai J Med 2012;79:433-50.

49. Cantor JC, Monheit AC, DeLia D, Lloyd K. Early impact of the Affordable Care Act on health insurance coverage of young adults. Health Serv Res 2012;47:1773-90.

50. Dow AW, Bohannon A, Garland S, Mazmanian PE, Retchin SM. The effects of expanding primary care access for the uninsured: implications for the health care workforce under health reform. Acad Med 2013;88:1855-61.
51. King J, Patel V, Jamoom EW, Furukawa MF. Clinical benefits of electronic health record use: national findings. Health Serv Res 2014;49(1 Pt 2):392-404.

52. DesRoches CM, Audet AM, Painter M, Donelan K. Meeting meaningful use criteria and managing patient populations: a national survey of practicing physicians. Ann Intern Med 2013;158:791-9.

53. HealthIT.gov. Health IT regulations. Meaningful use regulations. Available from: http://healthit.gov/policyresearchers-implementers/meaningful-use-regulations. Accessed September 20, 2014.

54. Bazemore AW, Petterson S, Johnson N, et al. What services do family physicians provide in a time of primary care transition? J Am Board Fam Med 2011; 24:635-6.

55. Tong ST, Makaroff LA, Xierali IM, et al. Proportion of family physicians providing maternity care continues to decline. J Am Board Fam Med 2012;25: $270-1$.

56. Cohen D, Coco A. Declining trends in the provision of prenatal care visits by family physicians. Ann Fam Med 2009;7:128-33.

57. Robert Graham Center: Policy Studies in Family Medicine and Primary Care. The diminishing role of FPs in caring for children. Am Fam Physician 2006; $73: 1518$

58. Bazemore AW, Makaroff LA, Puffer JC, et al. Declining numbers of family physicians are caring for children. J Am Board Fam Med 2012;25:139-40.

59. Sharma G, Fletcher KE, Zhang D, Kuo YF, Freeman JL, Goodwin JS. Continuity of outpatient and inpatient care by primary care physicians for hospitalized older adults. JAMA 2009;301:1671-80.

60. Harbuck SM, Follmer AD, Dill MJ, Erikson C. Estimating the number and characteristics of hospitalist physicians in the United States and their possible workforce implications. Analysis in Brief 2012;12. Washington, DC: Association of American Medical Colleges; 2012. https://www.aamc.org/download/300620/data/ aibvol12_no3-hospitalist.pdf. Accessed September 20, 2014.

61. Petterson S, Bazemore AW, Phillips RL, et al. Rewarding family medicine while penalizing comprehensiveness? Primary care payment incentives and health reform: the Patient Protection and Affordable Care Act (PPACA). J Am Board Fam Med 2011;24: 637-8.

62. Norris TE. Family practice OB: to be or not to be? Liability is the question. J Am Board Fam Pract 2003;16:565-6.

63. Rodney WM, Hardison D, Rodney-Arnold K, McKenzie L. Impact of deliveries on the office practice of family medicine. J Natl Med Assoc 2006;98:1685-90.

64. Scherger J. The scope of family medicine is expanding. Leawood (KS): Society of Teachers of Family Medicine; 2012. Available from: http://blog.stfm.org/2012/ 05/10/the-scope-of-family-medicine-is-expanding. Accessed January 30, 2014. 
65. Institute of Medicine. Primary care and public health exploring integration to improve population health. Washington, DC: National Academies Press; 2012.

66. Carney PA, Eiff MP, Green LA, et al. Preparing the personal physician for practice $\left(\mathrm{p}^{4}\right)$ : site-specific innovations, hypotheses, and measures at baseline. Fam Med 2011;43:464-71.

67. Fernald DH, Deaner N, O’Neill C, Jortberg BT, degruy FV 3rd, Dickinson WP. Overcoming early barriers to $\mathrm{PCMH}$ practice improvement in family medicine residencies. Fam Med 2011;43:503-9.

68. Mazzone M, Krasovich S, Fay D, et al. Implementing radical curriculum change in a family medicine residency: the majors and masteries program. Fam Med 2011;43:514-21.

69. ACGME program requirements for graduate medical education in family medicine. Chicago: Accreditation Council for Graduate Medical Education; 2013. Available from: http://www.acgme.org/acgmeweb/Portals/0/PFAssets/ ProgramRequirements/120_family_medicine_07012014. pdf. Accessed September 20, 2014.

70. Newton W, Baxley E, Reid A, Stanek M, Robinson M, Weir S. Improving chronic illness care in teach- ing practices: learnings from the $\mathrm{I}(3)$ collaborative. Fam Med 2011;43:495-502.

71. Reid A, Baxley E, Stanek M, Newton W. Practice transformation in teaching settings: lessons from the I(3) PCMH collaborative. Fam Med 2011;43: 487-94.

72. Bieck AD, Biggs WS, Crosley PW, Kozakowski SM. Results of the 2012 National Resident Matching Program: family medicine. Fam Med 2012;44:615-9.

73. Biggs WS, Crosley PW, Kozakowski SM. Results of the 2013 National Resident Matching Program: family medicine. Fam Med 2013;45:647-51.

74. ABFM Maintenance of Certification for family physicians. Lexington (KY): American Board of Family Medicine; 2014. Available from: https://www.theabfm. org/moc/index.aspx. Accessed June 2, 2014.

75. Xierali IM, Rinaldo JC, Green LA, et al. Family physician participation in maintenance of certification. Ann Fam Med 2011;9:203-10.

76. Galliher JM, Manning BK, Petterson SM, et al. Do professional development programs for Maintenance of Certification (MOC) affect quality of patient care? J Am Board Fam Med 2014;27:19-25. 